\title{
$\mathfrak{D a}$ \\ alfe und das nene \\ bürgerliche Recht \\ 刃ent

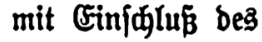 \\ Shandelstedts
}

Giftorifa und Dogmatifळ bargejtellt

von

\section{A. (Engelmanm,}

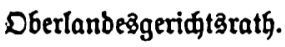

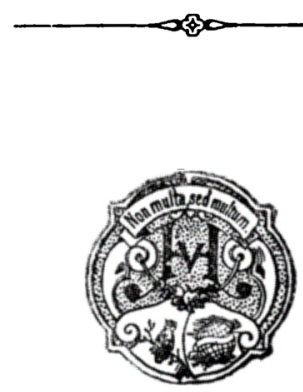

Berlin 1899.

I. X. Teine Bexlag. 
